23. Anello $\mathrm{C}$. Adverse behaviour reactions attributed to triazolam in the FDA's Spontaneous Reporting System. Presentation to the Pharmacological Drugs Advisory Committee Meeting on Sept 22, 1989, Washington, DC.

24. Kales A, Manfredi RL, Vgontzas AN, Bixler EO, Vela-Bueno A, Fee EC. Rebound insomnia following only brief and intermittent use of rapidly eliminated benzodiazepines. Clin Pharm Ther 1991; 49: 468-76.

25. Bixler EO, Scharf MB, Soldatos CR, Mitsky DJ, Kales A. Effects of hypnotic drugs on memory. Life Sctences 1979; 25: 1379-88.

26. Gold PE, Zornetzer SF. The mnemon and its juices: neuromodulation of memory processes. Behavioral Neural Biol 1983; 38: 151-89.

27. Kales A, Vgontzas AN. Not all benzodiazepines are alike. In: Stefanis $\mathrm{CN}$, Rabavilas AD, Soldatos CR (eds). Psychiatry: a world
perspective-Vol 3. Amsterdam: Elsevier Science Publishers, 1990: $379-84$.

28. Halcion 0.5 mg suspended in France. Scrip 1987; 1189: 34.

29. Halcion 0.5 mg Italian suspension (F). Scrip 1987; 1207: 27.

30. $0.5 \mathrm{mg}$ Halcion withdrawn in FRG. Scrip 1988; 1296: 3.

31. Triazolam. Inform Pharmaceutiques OMS 1988; 2: 32.

32. Kales A, Bixler EO, Vela-Bueno A, et al. Comparison of short and long half-life benzodiazepine hypnotics: triazolam and quazepam. Clin Pharmacol Ther 1986; 40: 378-86.

33. Seidel WF, Cohen SA, Bliwise NG, Roth T, Dement WC. Dose-related effects of triazolam and flurazepam on a circadian rhythm insomnia. Clin Pharm Ther 1986; 40: 314-20.

34. Oswald I. Triazolam syndrome 10 years on. Lancet 1989; ii: 451-52.

\title{
Rib infarcts and acute chest syndrome in sickle cell diseases
}

\author{
DONALD L. RUCKNAGEL KAREN A. KALINYAK \\ MICHAEL J. GELFAND
}

In the absence of evidence for pneumonia or pulmonary embolus, primary pulmonary infarction has been assumed to be the cause of the syndrome of chest pain, fever, and pulmonary infiltrate on chest $X$-ray that commonly complicates sickle cell anaemia. To find out whether the syndrome might be due to rib infarction, $99 \mathrm{mT}$-diphosphonate bone scans were done. In the eleven episodes thus investigated (10 patients) the scans showed segmental areas of increased radionuclide uptake in ribs, indicative of bone infarction. A possible sequence of events is that the rib infarcts are primary and cause bone pain, followed by soft tissue reaction, pleuritis, and splinting. The resultant hypoventilation leads to atelectasis and subsequent development of the radiographic changes of the acute chest syndrome. Prevention of hypoventilation and treatment of bone pain are important therapeutic goals.

Lancet $1991 ; 337: 831-33$

\section{Introduction}

The cause of "acute chest syndrome" (ACS) 1 in sickle cell anaemia - chest pain, with or without fever, and pulmonary infiltrate-has been said to be infarction of the lung. ${ }^{2-5}$ In a preliminary report we mentioned chest wall tenderness and scintigraphic evidence of rib infarction in patients with sickle cell diseases and ACS. ${ }^{6}$ Here we give the details.

\section{Methods}

The patients were admitted or referred for consultation at the University of Michigan Medical Center or the Children's Hospital Medical Center in Cincinnati. Laboratory investigations were done according to standard techniques at these institutions and in the course of routine care. In addition, radionuclide bone scans were done with standard gamma cameras after intravenous injection of $99 \mathrm{~m}^{\mathrm{T}} \mathrm{T} \mathrm{c}$-labelled etidronate or medronate.

\section{Results}

10 patients aged 13 to 35 years with sickle cell disease $(11$ $\mathrm{s} / \mathrm{s}, 1 \mathrm{~s} / \mathrm{c}$ genotype) had eleven episodes of rib infarction as shown by abnormal bone scans. Their clinical features (table) consisted of various combinations of pleurisy, fever, cough, chest wall tenderness, pleural effusion, and radiographic infiltrate. All blood or sputum samples sent for culture from ten of the eleven episodes were negative for known pathogens. The haematological indices were as expected for subjects with the disorder.

\section{Case-reports}

Patient 1-A 20-year-old man was admitted to hospital with a 2-day history of pleuritic chest pain. Physical examination revealed rib tenderness. Chest X-ray was normal, but $48 \mathrm{~h}$ later bilateral infiltrates, atelectasis, and pleural effusion were present. Posterior (fig 1) and left lateral (fig 2) bone scan images showed increased radiopharmaceutical uptake in defined segments of tender ribs.

Patient 4-The bone scan done a week after onset of symptoms was interpreted as negative, despite chest wall tenderness. A bone scan repeated 2 months later because of clinically evident infarction of the tibia showed increase of radiopharmaceutical uptake in segments of several ribs, even though the patient had had no new chest pain or other symptoms during the 60 day interval; the scan was interpreted as showing repair of bone infarction associated with the previous episode of chest pain.

Patient 8-He had two attacks of chest pain a month apart, with rib infarction demonstrated on the first episode and new bone scan abnormalities on the second. Several months later the manubrium sternae became exquisitely tender and the overlying tissue swollen and hot to touch.

ADDRESSES: Departments of Human Genetics and Internal Medicine, University of Michigan Medical School Ann Arbor, Michigan (D. L. Rucknagel, MD); Comprehensive Sickle Cell Centre, Children's Hospital Medical Center, Elland and Bethesda Aves, Cincinnati, Ohio (D. L. Rucknagel, K. A. Kalkinyak, MD): and Division of Radiology, Children's Hospital Medical Center, and Radioiostope Laboratory, Department of Radiology, University of Cincinnati, Cincinnati, Ohio (M. J. Gelfand, MD). Correspondence to Prof D. L. Rucknagel, Children's Hospital Medical Center, Elland and Bethesda Aves, Cincinnati, Ohıo 45229, USA 
CLINICAL FEATURES OF ELEVEN EPISODES OF ACS

\begin{tabular}{|c|c|c|}
\hline Feature & $\begin{array}{c}\text { Number of } \\
\text { episodes in } \\
\text { which feature } \\
\text { occurred }\end{array}$ & $\begin{array}{c}\text { Time of first } \\
\text { occurrence/detection } \\
\text { of featuret }\end{array}$ \\
\hline $\begin{array}{l}\text { Symptoms } \\
\text { Pleuritic chest pain } \\
\text { Non-pleuritic chest } \\
\text { pain } \\
\text { Abdominal pain } \\
\text { Bone pain (not rib) } \\
\text { Fever } \\
\text { Cough } \\
\text { Physica/ signs } \\
\text { Rib tenderness } \\
\text { Rales } \\
\text { Effusion } \\
\text { Consolidation } \\
\text { Infiltrate } \\
\text { Rib infarct on scan }\end{array}$ & $\begin{array}{l}6 \\
2 \\
4 \\
7 \\
6 \\
\\
8(1)^{\star} \\
5(1)^{\star} \\
8 \\
5(1)^{\star} \\
5 \\
11\end{array}$ & $\begin{array}{l}-2,-3,-3,-2, \mathrm{~A} \\
-2,-6, \mathrm{~A},+1,-2,-2 \\
\mathrm{~A}, \mathrm{~A} \\
-3,-1, \mathrm{~A},-2 \\
-3,+2,-4,+3,+1,+1, \mathrm{~A} \\
+2,-3,+2,+1,+2,+1 \\
+2,-1,+1,-2,-2, \mathrm{~A}, \mathrm{~A}, \mathrm{~A} \\
\mathrm{~A}, \mathrm{~A}, \mathrm{~A},+3,+1 \\
+2, \mathrm{~A},+2,+7, \mathrm{~A},+1, \mathrm{~A},+1 \\
+2, \mathrm{~A}, \mathrm{~A}, \mathrm{~A}, \mathrm{~A} \\
+2, \mathrm{~A},+4, \mathrm{~A}, \mathrm{~A}, \mathrm{~A} \\
+7,+7,+6,+60,+60,+15, \\
+7,+5,+31,+16,+4\end{array}$ \\
\hline
\end{tabular}

*Number of episodes of definite sign given, with number of occasions when sign uncertain given in brackets

Each patient had between three and ten of the twelve features listed.

$\dagger \mathrm{A}=$ day of admission, numbers refer to number of days preceding $(-)$ or following

$(+)$ admission

The corresponding region of the sternum showed increased radionuclide uptake. Sterile pus consisting only of neutrophils and debris was aspirated from the affected area through a Turkel needle; the patient had received no antibiotics during that episode.

Other patients-Among the remaining episodes one (patient 2) seemed to have been precipitated by a delayed

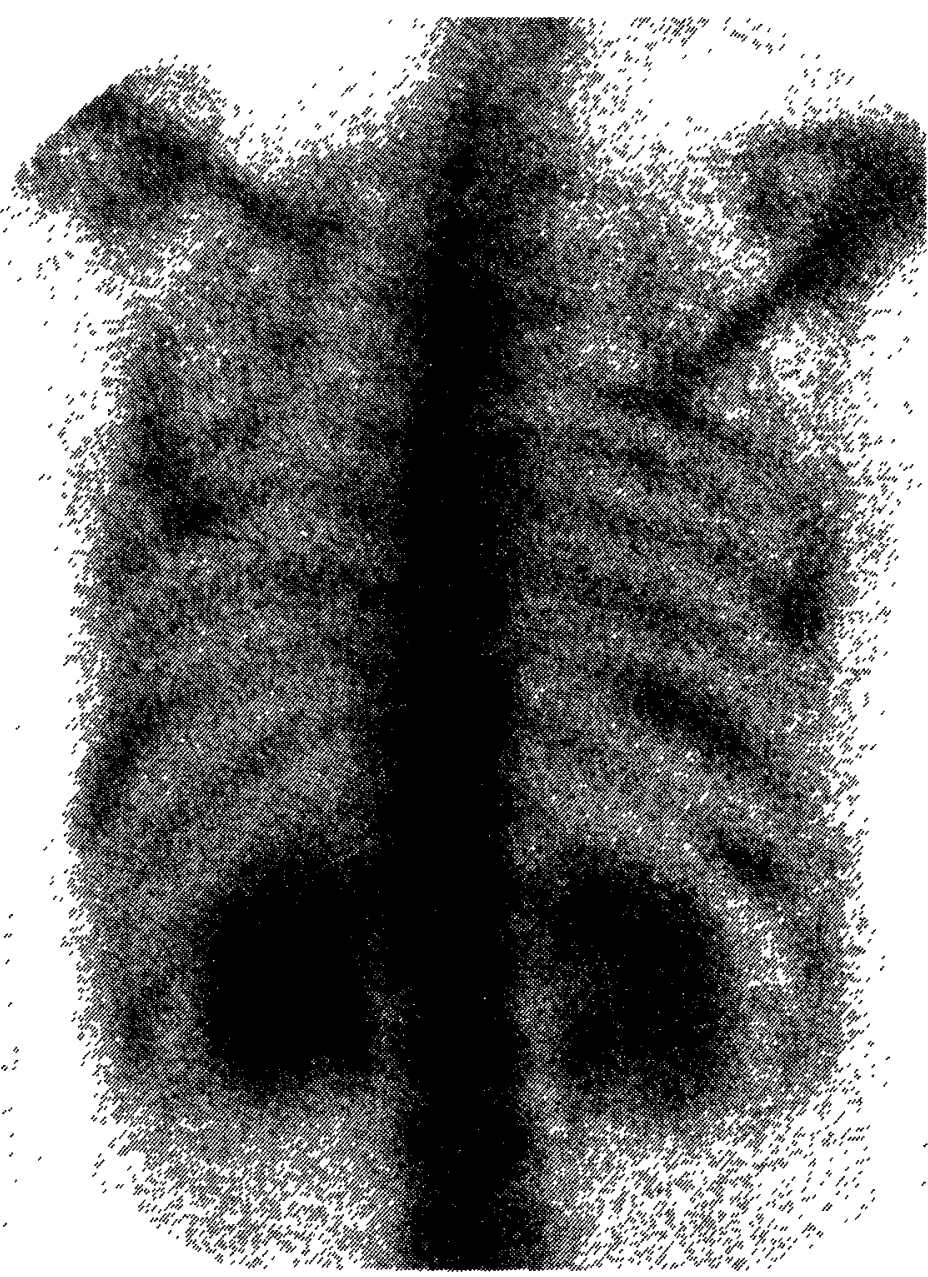

Fig 1-Posterior view of patient 5 showing multiple areas of increased radiopharmaceutical uptake in the ribs, consistent with bone infarction.

Delayed renal excretion is also seen, a common finding in adolescent and post-adolescent patients with sickle cell anaemia

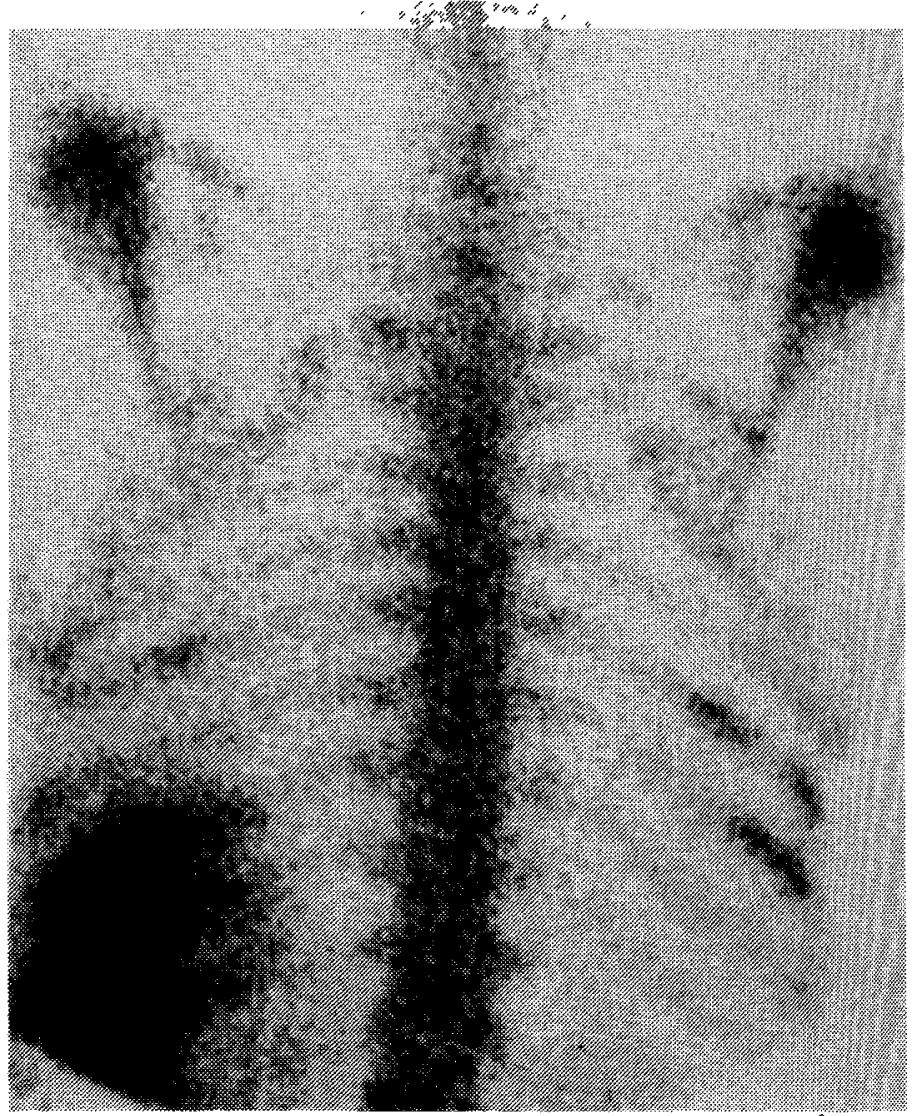

Fig 2-Bone scintigram of chest of patient 7 showing scattered areas of increased radiopharmaceutical uptake in the posterior ribs, consistent with bone infarction.

Splenic uptake is also seen.

transfusion reaction. The episode in patient 5 occurred immediately after exercise for a stress test.

\section{Discussion}

Pulmonary complications of sickle cell anaemia include predisposition to pneumonia, multiple pulmonary emboli, ${ }^{3,7,8}$ and embolisation of necrotic fat from infarction of bone. ${ }^{8}$ Chronic pulmonary disease may ensue. ${ }^{9}$ Evidence that pneumonia is the cause of ACS is sparse, either in children ${ }^{10}$ or in adults, in whom bacterial pneumonia has been associated with only some cases of ACS. ${ }^{1,47,11}$ Purulent sputum and hemoptysis, prevalent in pneumonia, are less evident in ACS. ${ }^{12}$ Besides, pathogenic bacteria were not cultured from our patients, and the 4 patients with pleurisy did not have preceding symptoms of acute upper respiratory symptoms.

The paucity of evidence for an infectious cause or thromboembolism led to the term "acute chest syndrome" $(A C S)^{1}$ and to the suggestion that the syndrome $e^{1-3,4,12,13}$ is due to lung infarction. ACS accounts for approximately $25 \%$ of hospital admission and deaths ${ }^{14,15}$ of patients with sickle cell anaemia. Although three-quarters of patients with ACS present with recognisable signs and symptoms, ${ }^{5}$ the syndrome may be preceded by pain elsewhere. Repeated attacks of ACS seem to be an important risk factor for chronic lung disease in persons with sickle cell syndromes. ${ }^{15}$

The biopsy findings in patient 8 support the supposition that the increases in radiopharmaceutical uptake by the ribs are due to the osteoblastic activity accompanying the repair process that follows marrow infarction. Others have also shown histologically ${ }^{16,17}$ and by radionuclide bone scanning ${ }^{18-20}$ that bone infarction in sickle cell anaemia is due to vaso-occlusion. The hand and foot syndrome and infarction of the anterior tibia have been accompanied by 
soft tissue swelling adjacent to the infarcted bone, so we propose that rib infarction might also cause local soft tissue reaction and pleuritic pain. Splinting and hypoventilation secondary to pain then leads to atelectasis and the radiographic changes of pneumonia, with effusion following on from pleural or pulmonary involvement. In our patients pulmonary infiltrate could take up to 4 days to evolve. Pleural effusion, also observed in the ACS by others, ${ }^{7,11,12}$ was detected in 8 of the 11 episodes we describe.

The most characteristic clinical finding in our patients is the rib tenderness. Rib tenderness is often difficult to evaluate because of patient resistance to manouvres that may be uncomfortable. Since radionuclide uptake may not increase until sufficient osteoblast mobilisation for repair has occurred (eg, patient 4) we suggest that the bone scan be delayed until at least 48-72 $\mathrm{h}$ after admission; and since the increased radionuclide uptake may persist for weeks (patients 4 and 8 ), the patient's history must be taken into account in interpreting the bone scan. Case 4 is the only instance in which increased rib uptake was an incidental finding when scanning was done for some other purpose.

Rib infarction and ACS are usually but not always present at the same time. In three of the eleven episodes in this study, bone scan changes consistent with rib infarction were present in the absence of consolidation, infiltrate, or effusion. We have continued to note that some patients will have bone scan changes without infiltrate or effusion, but we have only rarely seen radiographic evidence of ACS in the presence of a normal bone scan.

Although some workers advocate intravenous narcotic analgesia for analgesia in $\mathrm{ACS},{ }^{5,13}$ an association between the severity of the ACS and the use of narcotic analgesics has been reported. ${ }^{4,5.13}$ The speculation is that possible respiratory suppression by the narcotic analgesics might have led to atelectasis, hypoxia, and pulmonary intravascular sickling. However, the association reported does not necessarily imply cause and effect, nor does it exclude rib infarction as a cause of ACS. If rib infarction is the primary event, intensive effort to control pain rather than limitation of analgesia may be required to forestall atelectasis: but since large doses of narcotics may suppress the cough reflex and cause atelectasis, even in the absence of ACS, measures must also be taken to prevent hypoventilation-for example, by use of the incentive spirometer.

This work was funded by USPHS-HL-15996 and USPHS-HL-16008.

\section{REFERENCES}

1. Charache S, Scott JC, Charache P. 'Acute chest syndrome' in adults with sickle cell anemia. Arch Int Med 1979; 139: 67-69.

2. Smith EW, Conley CL. Clinical features of the genetic variants of sickle cell disease. Bull Fohns Hopkins Hosp 1954; 94: 289-318.

3. Barrett-Connor E. Acute pulmonary disease in sickle cell anemia. Am Rev Resp Dis 1971; 104: 159-65.

4. Palmer J, Broderick KA, Naiman JL. Acute lung syndrome during painful sickle cell crisis-relation to site of pain and narcotic requirement. Blood 1983; 62: 59a.

5. Sprinkle RH, Cole T, Smith S, Buchanan GR. Acute chest syndrome in children with sickle cell disease. Am f Ped Hematol/Oncol 1986; 8 105-10.

6. Rucknagel DL, Thrall JA, Kalinyak KA, Gelfand MJ. Rib infarcts may cause acute chest syndrome in sickle cell anemia. Blood 1988; 72: 71a.

7. Steinberg B. Sickle cell anemia. Arch Pathol 1930; 9: 876-97.

8. Oppenheimer EH, Esterly JR. Pulmonary changes in sickle cell disease. Am Rev Resp Dis 1971; 103: 858-89.

9. Bromberg PA, Jensen WN. Arterial oxygen unsaturation in sickle cell disease. Am Rev Respir Dis 1967; 96: 400-07.
10. Poncz M, Kane E, Gill FM. Acute chest syndrome in sickle cell disease: etiology and clinical correlates. $\mathcal{F}$ Pediatr 1985; 107: 861 66.

11. Barrett-Connor E. Pneumonia and pulmonary infarction in sickle cell anemia. $\mathcal{F} A M A$ 1973; $24: 997-1000$

12. Bromberg PA. Pulmonary aspects of sickle cell disease. Arch Intern Med 1974; 133: 652-57.

13. Cole TB, Sprenkle RH, Smith SJ, Buchanan GR. Intravenous narcotic therapy for children with severe sickle cell pain crisis. $A m \mathcal{F}$ Dis Child 1986; 140: 1255-59.

14. Thomas AN, Pattison CR, Serjeant GR. Causes of death in sickle-cell disease in Jamaica. Br Med f 1982; 285: 633-35.

15. Powars D, Weidman JA, Odom-Maryon T, Niland JC, Johnson C Sickle cell chronic lung disease: prior morbidity and the risk of pulmonary failure. Medicine 1988; 67: 66-76.

16. Diggs LW. Anatomic lesions in sickle cell diseases. In: Abramson $H_{\text {, }}$ Bertles JF, Wethers DL, eds. Sickle cell disease. Diagnosis, management, education, and research. St Louis: C. V. Mosby, 1973: 189-229.

17. Charache S, Page DL. Infarction of bone marrow in sickle cell disorders. Ann Intern Med 1967; 67: 1195-1200.

18. Milner PF, Brown $M$. Bone marrow infarction in sickle cell anemia: correlation with hematologic profiles. Blood 1982; 60: 1411-19.

19. Gelfand MJ, Harcke HT. Skeletal imaging in sickle cell disease. $\mathcal{f} \mathrm{Nucl}$ Med 1978; 19: 698

20. Sain A, Sham R, Silver L. Bone scan in sickle cell crisis. Clin Nuc Med 1978; 3: 85-90

\section{VIEWPOINT}

\section{Postmenopausal oestrogen and cardioprotection}

\section{JAN P. VANDENBROUCKE}

In the early 1960 s several researchers argued convincingly that oestrogens gave women the ultimate protection against all kinds of senescence; ${ }^{1,2}$ their arguments were based on clinical studies of osteoporosis and on epidemiological evidence indicating that, in women, oestrogens could delay the "natural" rise of cardiovascular disease with age. ${ }^{3}$ Today, the only remaining hot topic in the prevention of osteoporosis is whether postmenopausal oestrogen substitution should be universal or restricted to women at high risk. ${ }^{4}$ By contrast, the main cardiovascular debate is just beginning. ${ }^{5}$ In the early 1970 s doubts had been expressed about the cardioprotective effect of oestrogen when the results of clinical trials showed that oestrogen treatment given to prevent recurrence of cardiovascular events in men did more harm than good, ${ }^{3,6}$ and when it was realised that contraceptive oestrogen-progestagen preparations tended to increase the frequency of vascular disease in young women. By the mid-1970s some workers had abandoned the idea that oestrogens were the factor that protected women from cardiovascular disease. ${ }^{7}$

Why is the pendulum now swinging back to its original position? ${ }^{8-10}$ First, fresh epidemiological evidence has accrued on the effects of oestrogen substitution in older women; second, there is a momentum from the new professions of meta-analysis and cost-benefit analysis. That not all the latest epidemiological data sit perfectly in line has not deterred meta-analysts from sharpening their pens and streamlining the graphs to discredit some of the discordant

ADDRESS: Department of Clinical Epidemiology, Leiden University Hospital, PO Box 9600, 2300 RC Leiden, the Netherlands (Prof J. P. Vandenbroucke, MD) 